\title{
Long-term Effects of Propagation by Tissue Culture or Softwood Single-node Cuttings on Growth Habit, Yield, and Berry Weight of 'Northblue' Blueberry
}

\author{
Ahmed El-Shiekh ${ }^{1}$, David K. Wildung ${ }^{2}$, James J. Luby ${ }^{3}$, Kay L. Sargent ${ }^{2}$, and Paul E. Read ${ }^{4}$ \\ Department of Horticultural Science, University of Minnesota, St. Paul, MN 55108 and North Central \\ Experiment Station, University of Minnesota, Grand Rapids, MN 55744
}

Additional index words. micropropagation, Vaccinium spp.

\begin{abstract}
Plants of 'Northblue' blueberry, propagated in tissue culture (TC) or from softwood, single-node cuttings (ST), were evaluated in field plantings established in 1984 at Becker and Grand Rapids, in central and northern Minnesota, respectively. Plantings were observed from 1987 through 1994 to determine the persistence of such effects as increased vigor, more spreading growth habit, and higher yield observed for TC plants during the initial 3 years after planting. TC plants had significantly higher yields at Grand Rapids in 1989 and 1994. At Grand Rapids, the consistently greater plant spread (bearing area) of TC plants resulted in higher yields of TC plants over all years combined. At Becker, TC and ST plants did not differ for plant height or spread after 10 years and, in 2 of 5 years, ST plants had heavier average berry weights. At Grand Rapids, TC plants did not differ consistently in height, or subjective ratings of the amount of bloom or crop. The effects of propagation method on yield and growth habit of 'Northblue' are limited to early years in warmer locations, but can be of longer-term significance in colder areas with shorter growing seasons and lower winter temperatures, where plant spread is a more important factor than plant height in determining yield.
\end{abstract}

Highbush blueberry (Vaccinium corymbosum L.) cultivars are marginally hardy in Minnesota due to winter injury of branches bearing flower buds (Quamme et al., 1972). MN 360, a half-high genotype with low stature allowing for maximum snow cover was selected for possible introduction in 1973 (Quamme et al., 1972). After several years of propagation difficulties, MN 360 was released in 1983 as 'Northblue' (Luby et al., 1986). Softwood, single-node, leaf-bud cuttings (Stoutmeyer et al., 1933), which use plant material more efficiently than standard, multiple-node softwood or hardwood cuttings, were used to increase plant numbers of 'Northblue' before its release. The leaf-bud cutting technique was still not entirely satisfactory because rates of rooting and shoot growth were erratic (Parliman et al., 1974; Toivio, 1976). After several years of experiments (Grout, 1984; Haghighi, 1983), techniques were developed that enabled routine, commercial micropropagation of 'Northblue' and other half-high blueberries in the mid-1980s. Further research has also led to the refinement of micropropagation techniques for highbush (Rowland and Ogden, 1993; Wolfe et al., 1983; Zimmerman and Broome, 1980) and rabbiteye (Lyrene, 1980) blueberry cultivars.

Micropropagation of several fruit species has resulted in changes in growth habit. Shoot growth, cane diameter and lateral branching, flower production, and yield were all greater with micropropagated plants of thornless blackberry (Swartz et al., 1983). Micropropagated strawberries also grew more vigorously, producing

Received for publication 8 June 1995. Accepted for publication 13 Nov. 1995 Scientific journal series paper no. 21,884 of the Minnesota Agricultural Experiment Station. We gratefully acknowledge the assistance of Jeanne Grout, Tom Carpenter, Carol Cooper, Richard Harrison, Chad Finn, Barb Fick, Debby Filler, Kevin Iungerman, Amy Moberg, Margaret Stahler, and Doug Foulk in collecting data The cost of publishing this paper was defrayed in part by the payment of page charges. Under postal regulations, this paper therefore must be hereby marked advertisement solely to indicate this fact.

${ }^{1}$ Dept. of Horticulture, College of Agriculture, Suez Canal Univ., Ismailia 41522, Egypt.

${ }^{2}$ North Central Experiment Station, Univ. of Minnesota, Grand Rapids, MN 55744. ${ }^{3}$ Dept. of Horticultural Science, Univ. of Minnesota, St. Paul, MN 55108.

${ }^{4}$ Dept. of Horticulture, Univ. of Nebraska, Lincoln, NE 68588. more crowns and late runners than traditional runner-propagated plants (Damiano, 1980; Swartz, et al., 1981).

In earlier work, Grout et al. (1986) reported that 'Northblue' blueberry plants micropropagated in tissue culture (TC plants) had differences in branching pattern and vegetative growth compared to plants propagated from softwood, leaf-bud cuttings (ST plants). The vegetative growth rate of the young TC plants was three times the rate of young ST plants. Two to three times more basal branches were formed on TC plants by the time they were 27 to 34 weeks old. These differences in basal branches were maintained as the plants were transplanted to the field, where lateral branching on a per plant basis was also 2-fold greater in TC plants, though the average lateral branch length was similar in both types of plants. TC plants had similar numbers of total flower buds and total buds per lateral branch compared to ST plants, but TC plants produced more flower buds per plant during the first season in the field, suggesting a higher yield potential in the second season. Hartley (1986) and Read et al. (1989) determined that fruit yields of TC plants were, indeed, significantly higher through the first 3 years of harvest (1985-87), though average berry weight was not different. They also reported that plants propagated via TC had maintained a bushier, more spreading growth habit, resulting in a greater number of flower buds and hence better yield.

Using the same plantings of 'Northblue' established by Grout et al. (1986), our objective in this study was to determine whether differences in yield and vegetative growth between TC plants and ST plants are maintained over the long term.

\section{Materials and Methods}

Plantings of 'Northblue' established by Grout et al. (1986) were continued for this study. The planting at Becker, in central Minnesota, was established in 1984 as described by Grout et al. (1986). Hartley (1986) and Read et al. (1989) reported yield and growth data from this trial from 1984-86. We harvested six TC plants and six ST plants in each of four blocks from 1987-92. Plants were randomized in each block as noncontiguous, single-plant plots. Plots received overhead irrigation as needed and were fertilized 
Table 1. Performance of 'Northblue' blueberry plants produced by micropropagation (TC) or softwood, single-node cuttings (ST) in 5 years at Becker, Minn.

\begin{tabular}{|c|c|c|c|}
\hline Years & $\begin{array}{c}\text { Propagation } \\
\text { method }\end{array}$ & $\begin{array}{c}\text { Yield } \\
\text { (g/plant) }\end{array}$ & $\begin{array}{l}\text { Berry wt } \\
(\mathrm{g})\end{array}$ \\
\hline \multirow[t]{2}{*}{1987} & $\mathrm{TC}$ & $835^{\mathrm{NS}}$ & $1.99^{*}$ \\
\hline & ST & 765 & 2.14 \\
\hline \multirow[t]{2}{*}{1988} & $\mathrm{TC}$ & $1367^{\mathrm{NS}}$ & $1.40^{\mathrm{NS}}$ \\
\hline & ST & 1309 & 1.47 \\
\hline \multirow[t]{2}{*}{1989} & $\mathrm{TC}$ & $1235^{\mathrm{NS}}$ & $1.81^{*}$ \\
\hline & ST & 1481 & 1.94 \\
\hline \multirow[t]{2}{*}{1990} & $\mathrm{TC}$ & NA & NA \\
\hline & ST & NA & NA \\
\hline \multirow[t]{2}{*}{1991} & $\mathrm{TC}$ & $2416^{\mathrm{NS}}$ & $1.71^{\mathrm{Ns}}$ \\
\hline & ST & 2601 & 1.71 \\
\hline \multirow[t]{2}{*}{1992} & $\mathrm{TC}$ & $3569^{\mathrm{NS}}$ & $1.48^{\mathrm{NS}}$ \\
\hline & ST & 3861 & 1.54 \\
\hline \multirow[t]{2}{*}{ All years } & $\mathrm{TC}$ & $1884^{\mathrm{NS}}$ & $1.68^{\mathrm{NS}}$ \\
\hline & ST & 2003 & 1.76 \\
\hline
\end{tabular}

Ns, ${ }^{*}$ Nonsignificant or significant at $P \leq 0.05$.

with ammonium sulfate (100 kg/ha) in late April and mid-June of each year. Plants were not pruned. Harvesting was done by hand, usually at weekly intervals, for 2 to 5 weeks, depending on the season. Netting was placed over the plants to exclude birds. Total yield was recorded, and a sample of 25 berries was weighed on each harvest date and used to calculate the average berry weight over the season. In 1994, plants were measured for height and spread (diameter) within the row and spread perpendicular to the direction of the row.

At Grand Rapids, in northern Minnesota, plants from the initial 1984 planting were dug and moved to a new site in 1987 due to loss of a lease on the initial site. Block associations were maintained at the new site, and the TC and ST plants were randomized as plots of four contiguous plants in each of four blocks. The spacing was $1.3 \mathrm{~m}$ within rows and $2.6 \mathrm{~m}$ between rows. Fertilization, bird exclusion, and irrigation practices were the same as at Becker, except that trickle rather than overhead irrigation was used. In addition, floating row cover was used to protect the planting each winter beginning in 1988-89. These plants were harvested from 1989-94 in the manner described above. Plants were measured for height and spread within the rows in the spring after winter-injured stems had been removed and in the fall after growth had ceased. Plants were not pruned other than removal of injured wood. Plants were subjectively rated on a scale from one to nine for amount of winter injury, amount of bloom, and amount of crop, relative to the size of the plant. A rating of nine represented no winter injury, and very heavy bloom or crop relative to the size of the plant. A rating of one represented severe winter injury, no bloom, or no crop. Plants were also rated for vigor based on number of new shoots and length of shoot growth with a rating of nine representing high vigor and a rating of one representing low vigor.

Analyses of variance were conducted for each trait, at each location, using the Statistix 4.0 program (Analytical Software, Tallahassee, Fla.). Data over all combined years were analyzed using a split block design (Steele and Torrie, 1980) with propagation methods as fixed effects and years as random effects. Satterthwaite's (1946) approximation was used to estimate the appropriate denominator for $\mathrm{F}$ tests of propagation methods. Data from each year were also analyzed separately as a randomized complete block design.

\section{Results}

At Becker, the analyses of variance over all combined years (not shown) revealed significant $(P \leq 0.01)$ year effects for both total yield and berry weight. However, propagation method and propagation method $\times$ year interactions were not significant $(P>0.10)$ for total yield and berry weight. No significant differences in total yield were observed in any individual year (Table 1); however, ST plants had significantly $(P \leq 0.05)$ higher berry weight in 1987 and 1989 (Table 1). No significant differences were found in plant height or spread between TC and ST plants (data not shown).

At Grand Rapids, the analyses of variance over all combined years revealed that propagation method effects were significant for

Table 2. Mean squares from analyses of variance for effects of propagation methods on yield, berry weight, ratings for amount of bloom, winter injury, vigor, and crop rating, and plant height and spread of 'Northblue' blueberry plants over 7 years at Grand Rapids, Minn.

\begin{tabular}{|c|c|c|c|c|c|c|c|}
\hline Source & $\mathrm{df}$ & Yield & $\begin{array}{c}\text { Berry } \\
\text { wt }\end{array}$ & $\begin{array}{l}\text { Winter injury } \\
\text { rating }\end{array}$ & $\begin{array}{c}\text { Bloom } \\
\text { rating }\end{array}$ & $\begin{array}{c}\text { Spring } \\
\text { ht }\end{array}$ & $\begin{array}{l}\text { Spring } \\
\text { spread }\end{array}$ \\
\hline$\overline{\text { Block }}$ & 3 & 31,654 & 0.022 & 0.025 & 0.113 & 45.64 & 22.5 \\
\hline Method & 1 & $871,500^{-}$ & 0.009 & 0.031 & 0.085 & 84.80 & $2686.1^{* *}$ \\
\hline Method $\times$ block & 3 & 31823 & 0.027 & 0.136 & 0.517 & 63.31 & 58.7 \\
\hline Year & 5 & $1,201,000^{* *}$ & $0.334^{* * *}$ & $6.763^{* *}$ & $7.190^{* *}$ & $385.22^{* *}$ & $380.3^{* *}$ \\
\hline Year $\times$ block & 15 & 17053 & 0.012 & 0.295 & 0.553 & 5.52 & 13.2 \\
\hline Method $\times$ year & 5 & $159800^{* * *}$ & $0.026^{* *}$ & 0.530 & 0.432 & 3.49 & 13.5 \\
\hline \multirow[t]{2}{*}{ Error } & 15 & 27,641 & 0.005 & 0.288 & 0.403 & 6.48 & 25.2 \\
\hline & & $\begin{array}{l}\text { Vigor } \\
\text { rating }\end{array}$ & $\begin{array}{c}\text { Fall } \\
\text { ht }\end{array}$ & $\begin{array}{c}\text { Fall } \\
\text { spread }\end{array}$ & $\mathrm{df}$ & $\begin{array}{l}\text { Crop } \\
\text { rating }\end{array}$ & \\
\hline Block & 3 & 0.284 & 87.55 & 72.7 & 3 & 0.190 & \\
\hline Method & 1 & $2.706^{*}$ & 82.01 & $2724.3^{* *}$ & 1 & 0.342 & \\
\hline Method $\times$ block & 3 & 0.240 & 85.70 & 90.9 & 3 & 0.467 & \\
\hline Year & 6 & $5.427^{* *}$ & $199.75^{* * *}$ & $646.4^{* * *}$ & 4 & $9.798^{* * *}$ & \\
\hline Year $\times$ block & 18 & 0.111 & 9.59 & 12.9 & 12 & 0.576 & \\
\hline Method $\times$ year & 6 & 0.171 & 6.26 & 15.8 & 4 & 0.098 & \\
\hline Error & 18 & 0.139 & 6.96 & 13.2 & 12 & 0.296 & \\
\hline
\end{tabular}

${ }^{* *, * * *}$ Significant at $P \leq 0.10,0.05$, or 0.01 , respectively. 
Table 3. Performance of 'Northblue' blueberry plants produced by micropropagation (TC) or softwood, single-node cuttings (ST) over 7 years at Grand Rapids, Minn.

\begin{tabular}{|c|c|c|c|c|c|c|}
\hline Year & $\begin{array}{l}\text { Propagation } \\
\text { method }\end{array}$ & $\begin{array}{c}\text { Yield } \\
\text { (g/plant) }\end{array}$ & $\begin{array}{l}\text { Berry } \\
\text { wt } \\
(\mathrm{g})\end{array}$ & $\begin{array}{l}\text { Winter } \\
\text { injury } \\
\text { rating }\end{array}$ & $\begin{array}{l}\text { Bloom } \\
\text { rating }^{z}\end{array}$ & $\begin{array}{l}\text { Crop } \\
\text { rating }^{z}\end{array}$ \\
\hline \multirow[t]{2}{*}{1988} & $\mathrm{TC}$ & NA & NA & NA & NA & NA \\
\hline & ST & NA & NA & NA & NA & NA \\
\hline \multirow[t]{2}{*}{1989} & $\begin{array}{l}\text { TC } \\
\text { NA }\end{array}$ & $922^{*}$ & $1.47^{\mathrm{NS}}$ & $6.51^{\mathrm{NS}}$ & & $6.27^{\mathrm{Ns}}$ \\
\hline & ST & 606 & 1.56 & 5.92 & 5.99 & NA \\
\hline \multirow[t]{2}{*}{1990} & $\mathrm{TC}$ & $930^{\mathrm{NS}}$ & $1.50^{\mathrm{NS}}$ & $5.98^{\mathrm{NS}}$ & $5.15^{\mathrm{NS}}$ & $5.78^{\mathrm{NS}}$ \\
\hline & ST & 741 & 1.54 & 6.67 & 5.76 & 5.47 \\
\hline \multirow[t]{2}{*}{1991} & $\mathrm{TC}$ & $195^{\mathrm{NS}}$ & $1.17^{\mathrm{NS}}$ & $5.08^{\mathrm{NS}}$ & $5.81^{\mathrm{NS}}$ & $3.75^{\mathrm{NS}}$ \\
\hline & ST & 140 & 1.14 & 4.91 & 5.52 & 3.69 \\
\hline \multirow[t]{2}{*}{1992} & $\mathrm{TC}$ & $420^{\mathrm{NS}}$ & $1.00^{\mathrm{NS}}$ & $6.06^{\mathrm{NS}}$ & $8.19^{\mathrm{NS}}$ & $5.68^{\mathrm{NS}}$ \\
\hline & ST & 365 & 1.06 & 6.19 & 7.93 & 5.61 \\
\hline \multirow[t]{2}{*}{1993} & $\mathrm{TC}$ & $666^{\mathrm{NS}}$ & $1.50^{\mathrm{NS}}$ & $5.51^{\mathrm{NS}}$ & $5.97^{\mathrm{NS}}$ & $6.68^{\mathrm{NS}}$ \\
\hline & ST & 475 & 1.31 & 6.10 & 6.32 & 6.71 \\
\hline \multirow[t]{2}{*}{1994} & $\mathrm{TC}$ & $1688^{*}$ & $1.51^{\mathrm{NS}}$ & $7.99^{\mathrm{NS}}$ & $7.14^{\mathrm{NS}}$ & $5.09^{\mathrm{NS}}$ \\
\hline & ST & 877 & 1.37 & 7.63 & 6.51 & 4.58 \\
\hline \multirow[t]{3}{*}{ All years } & $\mathrm{TC}$ & $803^{-}$ & $1.36^{\mathrm{NS}}$ & $6.19^{\mathrm{NS}}$ & $6.42^{\mathrm{Ns}}$ & $5.40^{\mathrm{NS}}$ \\
\hline & ST & 534 & 1.33 & 6.24 & 6.34 & 5.21 \\
\hline & & $\begin{array}{l}\text { Vigor } \\
\text { rating }^{z}\end{array}$ & $\begin{array}{c}\text { Spring } \\
\mathrm{ht}^{\mathrm{y}} \\
(\mathrm{cm}) \\
\end{array}$ & $\begin{array}{l}\text { Spring } \\
\text { spread }^{\mathrm{y}} \\
(\mathrm{cm})\end{array}$ & $\begin{array}{l}\text { Fall } \\
\mathrm{ht}^{\mathrm{y}} \\
(\mathrm{cm})\end{array}$ & $\begin{array}{c}\text { Fall } \\
\text { spread }^{\mathrm{y}} \\
(\mathrm{cm})\end{array}$ \\
\hline \multirow[t]{2}{*}{1988} & $\mathrm{TC}$ & $6.07^{\mathrm{NS}}$ & NA & NA & $51.8^{\mathrm{NS}}$ & $69.0^{\mathrm{NS}}$ \\
\hline & ST & 5.58 & NA & NA & 48.3 & 54.6 \\
\hline \multirow[t]{2}{*}{1989} & $\mathrm{TC}$ & $6.59^{\mathrm{NS}}$ & $44.1^{\mathrm{NS}}$ & $62.1^{*}$ & $49.0^{\mathrm{NS}}$ & $70.2^{\mathrm{NS}}$ \\
\hline & ST & 6.26 & 43.4 & 49.3 & 47.4 & 59.4 \\
\hline \multirow[t]{2}{*}{1990} & $\mathrm{TC}$ & $7.13^{\mathrm{NS}}$ & $51.9^{\mathrm{NS}}$ & $72.4^{*}$ & $52.6^{\mathrm{NS}}$ & $90.8^{*}$ \\
\hline & ST & 7.07 & 49.3 & 54.2 & 49.4 & 73.8 \\
\hline \multirow[t]{2}{*}{1991} & $\mathrm{TC}$ & $6.32^{\mathrm{NS}}$ & $43.6^{\mathrm{NS}}$ & $81.0^{*}$ & $47.2^{\mathrm{NS}}$ & $72.3^{*}$ \\
\hline & ST & 5.61 & 40.5 & 66.4 & 44.1 & 61.8 \\
\hline \multirow[t]{2}{*}{1992} & $\mathrm{TC}$ & $6.14^{\mathrm{NS}}$ & $47.3^{\mathrm{NS}}$ & $74.8^{\mathrm{NS}}$ & $42.8^{\mathrm{NS}}$ & $73.7^{*}$ \\
\hline & ST & 6.00 & 43.8 & 60.6 & 41.6 & 56.6 \\
\hline \multirow[t]{2}{*}{1993} & $\mathrm{TC}$ & $5.49^{\mathrm{NS}}$ & $33.1^{\mathrm{NS}}$ & $81.5^{*}$ & $48.3^{\mathrm{NS}}$ & $92.4^{*}$ \\
\hline & ST & 5.02 & 31.4 & 63.5 & 48.8 & 76.6 \\
\hline \multirow[t]{2}{*}{1994} & $\mathrm{TC}$ & $8.14^{*}$ & $36.5^{\mathrm{NS}}$ & $67.5^{\mathrm{NS}}$ & $39.3^{*}$ & $75.2^{*}$ \\
\hline & ST & 7.25 & 32.1 & 55.6 & 34.5 & 63.1 \\
\hline \multirow[t]{2}{*}{ All years } & $\mathrm{TC}$ & $6.55^{*}$ & $42.7^{\mathrm{NS}}$ & $73.2^{* *}$ & $47.3^{\mathrm{NS}}$ & $77.7^{\text {** }}$ \\
\hline & ST & 6.11 & 40.1 & 58.3 & 44.9 & 63.7 \\
\hline
\end{tabular}

${ }^{\mathrm{z} W i n t e r ~ i n j u r y, ~ a m o u n t ~ o f ~ b l o o m, ~ a m o u n t ~ o f ~ c r o p, ~ a n d ~ v i g o r ~ w e r e ~ r a t e d ~ o n ~ a ~ s c a l e ~ f r o m ~} 1$ to 9 with $1=$ severe winter injury, very small amount of bloom or crop, and very low vigor, respectively.

yPlants were measured for height and spread (diameter) within the rows in the spring after winter-injured stems had been removed and in the fall after growth had ceased.

NS,-,*,**N Nonsignificant, or significant at $P \leq 0.10,0.05$, or 0.01 , respectively.

yield $(P \leq 0.10)$, spring and fall spread $(P \leq 0.01)$, and vigor rating $(P \leq 0.01)$ (Table 2$)$. Year effects were significant $(P \leq 0.01)$ for all traits. Year $\times$ propagation method interactions were significant $(P$ $\leq 0.01$ ) for yield and berry weight.

No significant differences in winter injury rating, bloom rating, spring height, fall height or crop rating were found between TC and ST plants in 1988-1994, as well as over all years combined (Table 3). In 1988, data for total yield, berry weight, bloom and winter injury rating, spring height and spread, and crop rating were not collected because the plants had just been moved during the prior season. Likewise, data for crop rating were not available in 1989. In 1994, as well as in all combined years, TC plants were more vigorous than ST plants. TC plants were significantly $(P \leq 0.05)$ larger in spring spread than ST plants in individual years, except for 1992, as well as over all years combined $(P \leq 0.01)$. Also, TC plants were significantly $(P \leq 0.05)$ larger in fall spread than ST plants in each year, except for 1988 and 1989, as well as over all years combined $(P \leq 0.01)$.

No significant differences in average berry weight were observed between TC and ST plants in any single year (Table 3). TC plants had significantly $(P \leq 0.05)$ higher yields in 1989 and 1994 (Table 3). Over all years combined, no significant differences in berry weight were found between TC and ST plants; however, total yield was significantly higher in TC than in ST plants.

\section{Discussion}

During the early years of these plantings, TC plants produced more lateral branches and had greater spread, providing a larger framework for flower bud production during field establishment 
compared with standard leaf-bud propagation (Grout et al., 1986). As these plantings aged, TC and ST plants became similar in spread at Becker, while at Grand Rapids, TC plant spread remained greater than ST plant spread even after 10 years. Grand Rapids is $280 \mathrm{~km}$ north of Becker and has a cooler, shorter growing season and lower minimum temperatures in the winter. In other experiments, we have observed that these factors result in less growth at Grand Rapids, and smaller stature for plants of similar age. Variation in plant height from year to year at Grand Rapids (Tables 2 and 3) reflected differences in winter injury during periods of extreme cold in the winters of 1990-91 and 1991-92.

Yield at both locations was affected far more by year to year variation in climatic factors than by propagation method. For example, yields in 1991 at Grand Rapids were lower than adjacent years due to severe winter injury (Table 3). Conversely, yields in 1989, 1990, and 1994 were higher due to early, deep snowfall that provided protection from winter injury. At Becker, plants were not even harvested in 1990 when low temperatures combined with a lack of snow cover during the previous winter resulted in severe injury to all plants. Plants from the two propagation methods did not differ for yield at Becker in any year, while at Grand Rapids, TC plants had significantly higher yields in 1989 and 1994 (Tables 1 and 3). At Grand Rapids, a consistently greater plant spread of TC plants in each year resulted in higher yields in each year (though not always statistically significant) apparently leading to a significantly higher yield over all years combined (Tables 3 and 4). Similar results were obtained for vigor ratings (Tables 2 and 3 ).

Plant height and ratings of vegetative vigor in the field at 10 years after propagation was the same for TC- and ST-derived 'Northblue' plants indicating TC-induced vigor may be only a temporary phenomenon after removal from culture. Based on the subjective ratings of vigor, amount of bloom, and amount of crop at Grand Rapids, TC and ST plants can not be distinguished for these traits in later years by visual assessment.

Ephemeral effects related to TC have been observed in several other species. Tissue culture-induced vigor has been noted in azaleas (Ettinger, 1983; Smith, 1981). Increased branch formation of TC plants has also been seen on several bromeliad species (Mekers, 1977). Micropropagated thornless blackberries had greater total shoot growth, and formed more canes and lateral branches per plant than plants from softwood cuttings or tip layers at 1 year after propagation, but had similar lateral bud activity after 2 years (Swartz et al., 1983). Strawberry plants from tissue culture formed more crowns and runners resulting in a more dense stand compared with non-TC plants (Damiano, 1980; Swartz et al., 1981).

Several other studies have compared micropropagated and nonmicropropagated plants for yield or its components. A similar number of fruit per crown were formed on micropropagated and runner-propagated strawberry plants (Swartz et al., 1981). Most cultivars of thornless blackberry had similar number of flowers per inflorescence, or number of fruit per meter of cane (Swartz et al., 1983). In the field, micropropagated strawberry and thornless blackberry plants produced yields that were similar to nonmicropropagated plants, but berry weight was lower in the first year's crop on micropropagated plants (Damiano, 1980; Swartz et al., 1981, 1983). In previous studies with 'Northblue', Grout et al. (1986) reported that there was no difference in the number of flower buds per branch on TC and ST plants.

Hartley (1986) and Read et al. (1989) observed that TC plants had higher yields in the first 3 years after planting, and suggested that this could help a producer recover establishment costs more rapidly. The results of this study suggest that effects of propagation method on plant stature and yield of 'Northblue' can have long term consequences in colder areas (e.g., Grand Rapids) with shorter growing seasons and frequent winter injury. In these areas, plant spread is likely to be a more important yield factor than plant height. In warmer areas (e.g., Becker), effects of propagation method on yield may be more temporary.

\section{Literature Cited}

Damiano, C. 1980. Strawberry micropropagation, p. 11-22. In: Proc. Conf. Nursery Production of Fruit Plants through Tissue CultureApplications and Feasibility. USDA-SEA. Agr. Res. Results ARR-NE11.

Ettinger, T.L. 1983. Aseptic micropropagation of rhododendron 'P.J.M. hybrids'. MS thesis, Southern Illinois Univ., Carbondale.

Grout, J.M. 1984. The influence of stock plant propagation method on tissue culture and leaf-bud propagation of 'Northblue' blueberries. MS thesis, Univ. of Minnesota, St. Paul.

Grout, J.M., P.E. Read, and D.K. Wildung. 1986. Influence of tissue culture and leaf-bud propagation on the growth habit of 'Northblue' blueberry. J. Amer. Soc. Hort. Sci. 111:372-375.

Haghighi, K. 1983. Propagation of Minnesota blueberries through tissue culture. MS thesis, Univ. of Minnesota, St. Paul.

Hartley, C.A. 1986. In vitro propagation and field performance of Minnesota half-high hybrid blueberries. MS thesis, Univ. of Minnesota, St. Paul.

Luby, J.J., D.K. Wildung, C. Stushnoff, S.T. Munson, P.E. Read, and E.E. Hoover. 1986. Northblue, Northsky, and Northcountry blueberries. HortScience 21:1240-1242.

Lyrene,P.M. 1980. Micropropagation of rabbiteye blueberries. HortScience 15:80-81.

Mekers, O. 1977. In vitro propagation of some Tillandsioideae (Bromeliaceae). Acta Hort. 78:311-320.

Parliman, B., M. Toivio, and C. Stushnoff. 1974. Propagation procedures for new half-high blueberry hybrid. Proc. 3rd N. Amer. Blueberry Res. Workers Conf. Mich. Agr. Expt. Sta. Rpt.

Quamme, H.A., C. Stushnoff, and C.J. Weiser. 1972. Winter hardiness of several blueberry species and cultivars in Minnesota. HortScience 7:500-502.

Read, P.E., D.K. Wildung, and C.A. Hartley. 1989. Field performance of in vitro-propagated 'Northblue' blueberries. Acta Hort. 241:191-194.

Rowland, L.J. and E.L. Ogden. 1993. Efficient shoot regeneration from leaf sections of highbush blueberry suitable for use in Agrobacteriummediated transformations. Acta Hort. 336:193-197.

Satterthwaite, F.E. 1946. An approximate distribution of estimates of variance components. Biom. Bul. 2:110-114.

Smith, W.A. 1981. The aftermath of the test tube in tissue culture. Comb. Proc. Intl. Plant Prop. Soc. 31:47-49.

Steel, R.G.D. and J.H. Torrie. 1980. Principles and procedures of statistics. 2nd ed. McGraw-Hill, New York.

Stoutmeyer, V.T., T.J. Maney, and B.S. Pickett. 1933. A rapid method for propagating raspberries and blackberries by leaf-bud cuttings. Proc. Amer. Soc. Hort. Sci. 30:278-282.

Swartz, H.J., G.J. Galletta, and R.H. Zimmerman. 1981. Field performance and phenotypic stability of tissue culture-propagated strawberries. J. Amer. Soc. Hort. Sci. 106:667-673.

Swartz, H.J., G.J. Galletta, and R.H. Zimmerman. 1983. Field performance and phenotypic stability of tissue culture-propagated thornless blackberries. J. Amer. Soc. Hort. Sci. 108:285-290.

Toivio, M. 1976. Propagation of blueberries and azaleas from leaf-bud cuttings. MS thesis, Univ. of Minnesota, St. Paul.

Wolfe, D.E., P. Eck, and C.-K. Chin. 1983. Evaluation of seven media for micropropagation of highbush blueberry. HortScience 18:703-705.

Zimmerman, R.H., and D.C. Broome. 1980. Blueberry micropropagation, p. 44-47. In: Proc.Conf. Nursery Production of Fruit Plants through Tissue Culture-Applications and Feasibility. USDA-SEA. Agr. Res. Results ARR-NE-11. 